\title{
Teknik Stimulasi dalam Pendidikan Karakter Anak Usia Dini melalui Lirik Lagu Dolanan
}

\author{
Ana Rosmiati ${ }^{1}$ \\ Institut Seni Indonesia Surakarta
}

\begin{abstract}
ABSTRAK
Media musik melalui lirik lagu dolanan anak dapat membantu pembentukan karakater pada anak usia dini. Anak-anak dapat merasakan kehadiran musik sebagai sarana untuk menemani aktivitas dalam bermain. Teknik stimulasi melalui media musik ternyata memiliki dampak positif dalam perkembangan pembentukan emosional anak. Anak-anak bisa terkontrol emosinya dari kebiasaan yang tidak baik. Penelitian ini memakai teknik stimulasi melalui pemaknaan lirik lagu dolanan anak yang dapat membentuk karakter anak pada usia dini. Penelitian ini menggunakan metode deskriptif kualitatif yang mendeskripsikan secara sistematis, faktual dan akurat mengenai fakta-fakta, sifat, serta hubungan antara fenomena yang diselidiki. Penelitian ini mengidentifikasikan contoh pemaknaan lagu dolanan anak yang dapat membantu dalam pembentukan karakter pada anak-usia dini. Anak dapat menggali nilai-nilai kehidupan dari makna pada lirik lagu dolanan berupa nilai pendidikan, pengetahuan, religius, sosial, dan budaya.
\end{abstract}

Kata kunci: stimulasi, musik, lirik, dolanan, karakter dan anak

\begin{abstract}
The Stimulation Technique on the Character Education of Early Age Children through the Lyrics of Children's Song. The music media through the children's song lyrics can help building the children character of the early age children. Children can feel the presence of the music as the media for accompanying the children's play activities. The stimulation technique through the music media, in fact, has the positive impact in developing the children emotional building. The children are able to control their emotion away from the bad habits. The aim of the research is to find the appropriate stimulation technique through the understanding of the children's song lyrics which can be used to build children character in the early age. This research uses a qualitative descriptive method describing systematic, factual, and accurate information on the facts, nature, and the relationship between the phenomena investigated. The result of the research has been identified by some examples of children's songs which can help children in their character building since the early age. Children can explore their values of life from the meanings on the children's song lyrics which consist of values on education, knowledge, religious, social, and culture.
\end{abstract}

Keywords: stimulation, music, lyric, play, character and kid

\section{Pendahuluan}

Kehadiran musik dalam kehidupan manusia merupakan dua hal yang saling bersinergi. Musik dapat digunakan sebagai media pembentukan karakter pada anak usia dini. Pembentukan karakter dibutuhkan untuk menanamkan pendidikan, kepribadian, dan moral kepada anak usia dini. Sebagai contoh, lirik sebuah lagu dapat mempengaruhi kejiwaan anak-anak. Salah satunya dengan menciptakan lagu anak yang bertema nilai-nilai kebaikan yang dapat membangun kepribadian atau karakter pada anak. Pendidikan anak usia dini memiliki peran yang besar dalam membangun dan membentuk karakter jangka panjang pada anak. Orangtua memegang keberhasilan dan kesuksesan mendidik pada masa kecil. Perhatian dan kasih sayang menjadi kunci sukses keberhasilan dalam membentuk karakater pendidikan yang berkualitas pada anak.

Alamat korespondensi: Prodi Disain Komunikasi Visual, ISI Surakarta. Jln. Ki Hajar Dewantara, Jebres, Surakarta. HP: 08139385680o.E-mail: anarosmiati@yahoo.co.id 
Spradley (2007:15) menyampaikan bahwa dalam perkembangan peradaban dunia yang semakin maju, seseorang dapat mengalami peristiwa 'kebanjiran budaya' (culturally overnhelmed), yaitu munculnya pengaruh dua budaya atau lebih sekaligus, atau bersama-sama. Generasi muda yang belum menguasai budayanya sendiri, dan berhadapan dengan pengaruh berbagai budaya asing sebagai dampak dari canggihnya teknologi informasi, akan mengalami kebingungan karena belum mampu membedakan budaya yang baik dan cocok bagi dirinya. Akibatnya, seseorang akan mengalami ketercerabutan budaya. Hal itu terjadi karena selain tidak lagi mengenal budaya asli nenek moyangnya juga belum mampu 'memilih dan memilah', mana budaya baik yang sesuai karakter bangsanya.

Budaya modernisasi yang masuk ke Indonesia mempengaruhi berbagai hal termasuk dalam ranah musik. Mencermati kondisi yang ada, akhir-akhir ini banyak musik dari luar negeri yang diadopsi oleh para remaja Indonesia. Remaja beranggapan dengan menyenangi musik luar negeri berarti terjadi trend dalam dirinya. Remaja berasumsi bahwa menyenangi bahkan mempelajari musik gamelan adalah budaya yang kuno dan mengalami kemunduran. Bahkan yang mengejutkan anak kecil pun lebih hafal lirik lagu barat dibandingkan lirik lagu tembang anak-anak baik dalam bahasa Jawa (daerah) ataupun bahasa Indonesia.

Hastanto (2011:1) mengemukakan bahwa setelah merasa dirinya menjadi orang modern, biasanya mereka memandang remeh kapada apa saja yang berbau tradisi. Mereka mencapnya sebagai barang kuno dan ketinggalan zaman. Padahal dalam tradisi itulah terletak jati diri kita yaitu sesuatu yang membedakan kita dengan bangsa lain, sesuatu yang dapat mengangkat kita sebagai manusia yang bermartabat di mata dunia, justru hal itu yang mereka tinggalkan dan mereka berusaha masuk ke budaya lain yang tidak dimengertinya secara mendalam.

Berkaitan dengan itu, Syuhendri (2008:12) mengemukakan bahwa dalam memandang suatu budaya barat itu, lembaga pendidikan seni seyogyanya menjadi lembaga yang secara arif dapat memanfaatkan perkembangan pengetahuan barat yang lebih metodologis secara selektif, dengan tetap berpegang pola kulturalis. Barat dapat membantu dengan kemajuan teknologinya dan dengan metode pengetahuannya yang dapat digunakan sementara waktu, menjelang ditemukannya metode yang menyangkut pada budaya seni, untuk itu, diperlukan pemikiran kreatif dan pergaulan terus menerus dalam menemukan formulasi metodologis yang paling sesuai.

Musik barat dianggap lebih dinamis dan energik sehingga dapat menimbulkan nuansa yang mampu menggairahkan semangat para remaja sekarang. Hal ini terbukti banyaknya hiburan malam di sejumlah kota yang menyajikan life musik setiap harinya. Musik yang dihadirkan pun cenderung musik barat dibandingkan dengan musik Indonesia. Mencermati hal tersebut, dilakukan tindakan pencegahan, yaitu melalui media musik. Salah satunya dengan memperkenalkan lirik lagu yang dapat mempengaruhi perkembangan kepribadian anak tersebut. Musik yang ada di Indonesia terutama dari daerah dapat dipakai sebagai media penanaman budi pekerti pada karakter anak-anak. Isma'un (2014) mengemukan pada zaman dahulu, ketika malam padhang "terang bulan", anak-anak biasanya bersuka ria, menyayi dan menari dengan beberapa tembang yang lirikliriknya terkandung makna filosofi yang dalam. Misalnya lagu menthog-menthog dan lagu kupu kuwi. Kedua lagu tersebut mengenalkan binatang sesuai habitat dan kebiasannya. Hal yang lebih menyenangkan adalah anak-anak melakukannya dengan suka cita dan penuh kegembiraan menikmati masa kecilnya.

Berbeda kondisinya dengan masa sekarang ini, anak sekarang sudah tidak dapat menikmati malam bulan purnama dengan menyanyikan lagu dolanan anak tetapi gadget yang menemani setiap waktu luangnya. Tentunya ini mempengaruhi perkembangan kepribadian. Tidak hanya kepribadian tetapi juga sikap yang lebih apatis ketika anak mengisi hari-harinya dengan beraktivitas di dunia maya. Mereka lebih cenderung menikmati game-game online yang tersedia sehingga aktivitasnya hanya duduk sambil bermain fantasi dalam permainan tersebut. Kondisi inilah yang membuat penulis tertarik untuk melakukan 
penelitian mengenai teknik stimulasi yang tepat dalam menanamkan pendidikan karakter melalui makna dalam lirik lagu anak-anak.

Anak merespon secara positif melalui irama musik dengan menyanyikan lirik yang ada dalam lagu tersebut. Untuk menanamkan pendidikan karakter yang baik dibutuhkan lirik lagu yang mendidik. Peneliti memilih lagu dolanan anak yang memiliki muatan pendidikan, moral, kerjasama yang baik, maupun keagamaan. Setelah diamati teryata teknik stimulasi melalui musik ini membuat anak memiliki sifat perangai yang riang. Anak bisa bergerak leluasa dengan iringan musik sambil menyanyikan lirik lagunya. Secara emosi terbentuk karakter yang baik pada memorinya. Media pembelajaran melalui musik dirasa lebih efektif dan efisien bisa dimengerti dan dihafal oleh anak-anak. Secara tidak langsung anak-anak akan terbawa pada situasi yang menyenangkan sehingga secara emosional dapat terkontrol dengan baik. Secara alamiah anak-anak pun terbina karakter budi pekerti yang baik dari mempelajari makna lirik lagu-lagu dolanan anak-anak.

Musik yang hinggar binggar secara otomatis membuat tingkat emosional yang kurang baik pada perkembangan mental anak. Secara kesehatan pun ternyata memiliki efek yang kurang begitu baik. Begitupula watak perangainya juga akan terbentuk menjadi orang yang lebih agresif. Belum lagi kemungkinan meniru kostum yang kurang mendidik dengan budaya Indonesia yang masih dikatakan budaya timur.

Penelitian mengenai teknik stimulasi dalam pendidikan karakter anak pada usia dini melaui makna dalam lirik lagu dolanan anak ini menggunakan penelitian deskriptif kualitatif. Penelitian deskriptif bertujuan membuat deskripsi (gambaran) secara sistematis, faktual dan akurat mengenai fakta-fakta, sifat, serta hubungan antara fenomena yang diselidiki. Metode deskriptif yang digunakan bertujuan untuk memperoleh pemerian data yang akurat sehingga mempermudah proses analisis. Metode penelitian kualitatif merupakan prosedur penelitian yang menghasilkan data deskriptif berupa kata-kata tertulis atau lisan tentang sifat-sifat individu, keadaan, gejala, dari kelompok tertentu yang dapat diamati (Lexy, J.
Moleong, 2000: 6).

Data penelitian diperoleh dari hasil observasi, wawancara, dan dokumentasi terhadap informan yang sudah terseleksi. Informan dipilih secara berantai untuk lebih memperjelas data. Pendekatan yang digunakan adalah holistik dengan melibatkan semua komponen masyarakat, tindakan bersifat kreatif dan inovatif. Data penelitian ini dikumpulkan dengan teknik kajian pustaka, wawancara mendalam, dan observasi. Kajian pustaka dilakukan dengan mengkaji sumber data teks/dokumen yang berkaitan dengan tembang dolanan Jawa dan naskah-naskah budaya Jawa pada umumnya. Wawancara mendalam dilakukan dengan narasumber para guru PAUD/TKIT, masyarakat, budayawan, pakar pendidikan, psikolog anak, dan anak-anak PAUD/TKIT. Observasi dilakukan dengan dua cara yaitu observasi langsung dan tidak langsung. Observasi dilakukan dengan pengamatan aktivitas proses pembelajaran di beberapa PAUD dan TKIT di Surakarta. Selain itu, dilakukan pengamatan pada beberapa anak-anak yang sedang bermain-main di lingkungannya.

Wawancara dilakukan dengan dua cara, yaitu wawancara bebas dan terprogram. Wawancara bebas dilakukan terhadap beberapa informan dan narasumber untuk memperoleh data yang bersifat umum. Wawancara bebas sudah dilakukan sejak peneliti memasuki lapangan. Wawancara dimaksudkan untuk mengetahui media pembelajaran PAUD/TKIT, model pendidikan karakater, media stimulasi, perkembangan anak, dan teknik permainan. Wawancara ini bertujuan untuk memperoleh data yang asli tanpa rekayasa. Wawancara terprogram dilakukan untuk menggali data yang benar-benar diperlukan dalam penelitian. Wawancara terprogram berupa sejumlah daftar pertanyaan seputar pembelajaran di PAUD/TKIT. Wawancara juga dilakukan pada masyarakat, budayawan, dan komunitas anak-anak sebagai pembanding objek penelitian.

Teknik sampling digunakan dalam penelitian, adalah teknik purposive, snowball, dan time sampling. Teknik purposive untuk memilih sumber data yang sesuai dengan tujuan penelitian, misalnya memilih guru PAUD/TKIT. Teknik snowball 
sampling untuk menentukan informan kunci yang paling memahami data penelitian yang dibutuhkan, berdasarkan informasi dari narasumber yang satu untuk mengetahui narasumber lainnya, dan seterusnya. Teknik time sampling digunakan untuk memilih sumber data yang prosesnya terjadi pada waktu yang sama, antara objek dan subjek (narasumber), misalnya pada saat proses pembelajaran di PAUD/TKIT.

\section{Media Musik sebagai Penanaman Karakter Anak-Anak}

Makna pendidikan secara sederhana adalah usaha manusia untuk membina kepribadian sesuai dengan nilai-nilai dalam masyarakat dan kebudayaan. Hal ini dilakukan dengan membina potensi-potensi pribadi yang meliputi rohani dan jasmani. Pendidikan sebagai upaya pengembangan sumber daya manusia dalam arti seluas-luasnya dan kebudayaan sebagai milik seluruh bangsa, pada hakikatnya merupakan dua hal yang berkaitan erat, karena pendidikan berlangsung dalam iklim budaya tertentu. Pendidikan tidak dapat dilepaskan dari paradigma kebudayaan yang merupakan lahan bagi tumbuhnya identitas dan kepribadian bangsa (Soemaryatmi, 2010 :55). Berkaitan dengan itu, Karakter terbentuk sebagai hasil pemahaman dari hubungan dengan diri sendiri, dengan lingkungan (hubungan sosial dan alam sekitar), dan hubungan dengan Tuhan YME (triangle relationship)(Gutama, 2014).

Karakter adalah konsep psikologi yang kompleks. Di dalamnya, tercakup kapasitas berpikir tentang yang benar dan salah, pengalaman emosi moral (salah, empati, dan haru), terikat dalam perilaku moral (berbagi, dermawan, dan menceritakan kebenaran), keyakinan dalam kebaikan moral, mendemonstrasikan kecenderungan bertindak dengan jujur, mementingkan orang lain/altrusime, tanggung jawab, dan karakteristik lain yang mendukung fungsi moral (Berkowitz, 1992: 49).

Mochtar Buchori (2007) mengemukakan bahwa pendidikan karakter dapat dimaknai sebagai budi pekerti plus, yaitu melibatkan aspek pengetahuan (cognitive), perasaan (feeling), dan rmoral kepada pembelajar yang meliputi komponen pengetahuan, kesadaran, atau kemauan, dan tindakan untuk melaksanakan nilai-nilai tersebut baik kepada Tuhan Yang Maha Esa, diri sendiri, sesama, lingkungan maupun kebangsaan sehingga menjadi manusia insan kamil. Oleh karena itu, pendidikan karakter seharusnya membawa peserta didik ke pengenalan nilai-nilai secara kognitif, penghayatan nilai secara afektif, yang akhirnya bermuara pada pengamalan yang nyata.

Berkaitan dengan itu, Guntur (2010 : 8) mengemukakan bahwa karakter memiliki makna yang sangat beragam. Karakter ada kalanya dimaknai sebagai kebaikan atau eksentrisitas seseorang. Karakater dipandang bersifat sematamata personal, sementara yang lain lebih bersifat behavioral. Karakter dimaknai sebagai seperangkat karakteristik psikologi individu yang mempengaruhi kemampuan dan menimbulkan dorongan seseorang untuk memfungsikan secara moral. Secara sederhana karakter terdiri dari sifatsifat tersebut yang mengarahkan seseorang untuk melakukan secara benar atau tidak.

Tembang dolanan berbahasa Jawa merupakan sarana untuk bersenang-senang dalam mengisi waktu luang dan juga sebagai sarana komunikasi yang mengandung pesan mendidik. Contoh tembang dolanan yang dimaksud adalah CublakCublak Suweng, Jaranan, Padhang Bulan, Ilir-Ilir, dan masih banyak lagi. Tembang dolanan anak merupakan suatu hal yang menarik karena sesuai dengan perkembangan jiwa anak yang masih suka bermain. Suharko Kasaran (Ketua Komisi Nasional Budi Pekerti) mengatakan bahwa apabila anak kurang/tidak dibina pendidikan budi pekerti sedini mungkin, pada umur 14 tahun anak itu akan mengembangkan sikap destruktif (cenderung ke arah brutal). Kurangnya pembinaan atau pedidikan budi pekerti dibuktikan banyaknya kejadian di usia remaja dan dewasa atau tua seperti kenakalan remaja, tawuran massal, pelecehan seksual, dan sebagainya (wawancara Buletin Siang RCTI, 11 Mei 1999 dalam Yuyun Kartini).

Freud (Santrock \& Yussen, 1992; Solehuddin, 2000) memandang usia lima tahun pertama pada masa kanak-kanak sebagai masa terbentuknya kepribadian dasar individu. Kepribadian orang 
dewasa ditentukan oleh cara-cara pemecahan konflik antara sumber-sumber kesenangan awal dengan tuntutan realita pada masa kanak-kanak. Pada masa usia ini penuh dengan kejadian-kejadian yang penting dan unik (a hig hy event full and unigue period of life) yang meletakkan dasar bagi kehidupan seseorang di masa dewasa.

Berkaitan dengan itu, tujuan pendidikan kanak-kanak adalah untuk memfasilitasi pertumbuhan dan perkembangan anak secara optimal dan menyeluruh, sesuai dengan norma-norma dan nilai-nilai kehidupan yang dianut. Melalui pendidikan ini diharapkan anak dapat mengembangkan segenap potensi yang dimilikinya, yang mencakup aspek agama, intelektual, sosial, ekonomi, dan fisik, memiliki dasar-dasar akidah yang lurus/benar sesuai dengan ajaran agama yang dianutnya, memiliki kebiasaan-kebiasaan perilaku yang diharapkan, menguasai sejumlah pengetahuan dan ketrampilan dasar sesuai dengan kebutuhan dan tingkat perkembangannya, serta memiliki motivasi dan sikap bahasa yang selaras dengan perkembangan jaman.

Pendidikan adalah pembelajaran. Pembelajaran adalah langkah untuk mencapai pemahaman. Untuk memahami materi pendidikan diperlukan sebuah proses. Proses memerlukan semangat. Tujuan pendidikan akan tercapai apabila dilakukan dengan orientasi yang benar. Artinya orientasi pendidikan akan menumbuhkan semangat serta menuntun pemahaman kita dalam proses pembelajaran. Dengan demikian, dapat dikatakan bahwa hakikat pendidikan adalah penghargaan terhadap sebuah proses dan dilandasi dengan orientasi yang benar (Ekalaya, 2008: 20).

Teknik stimulasi dalam mendidik karakter pada anak-anak bisa melaluli musik, nyanyian, suara, gerakan, bicara, perabaan, membaca, mencocokkan, membandingkan, mengelompokkan, memecahkan masalah, mencoret, merangkai, maupun menggambar. Dari sekian teknik stimualasi ini, peneliti lebih cenderung menggunakan teknik melalui musik sebagai media pembentukan karakter pada anak. Teknik ini peneliti kompilasikan dengan mengambil sampel musik pada lagu dolanan anak, menginggat semakin langkanya lagu dolanan anak dan semakin hilang dari peredaran.
Lagu dolanan anak ini sudah mulai digantikan dengan beredarnya lagu-lagu dewasa yang semestinya belum boleh dikonsumsi oleh anak-anak.

Suharji (1977) mengemukakan bahwa budaya barat terutama musik telah banyak diadopsi oleh remaja di Indonesia. Hal ini tentu memiliki dampak yang kurang baik untuk perkembangan kepribadian para remaja. Sebagai solusinya, anak-anak mulai dikenalkan tentang kebudayaan Indonesia sejak dini. Budaya Indonesia yang memiliki nilai adiluhung harus bisa dilestarikan agar tidak tergeser dengan masuknya budaya barat yang sulit untuk di filter.

Lagu dolanan anak memiliki manfaat yang positif di dalam pembentukan karakter karena, mengandung nilai-nilai kependidikan di antaranya nilai kejujuran, kerukunan, sejarah, budaya, dan menghormati orang lain. Tidak hanya dari segi pendidikan, dari segi kesehatan ternyata permainan dalam dolanan anak memiliki manfaat untuk pembentukan fisik anak melalui gerakan-gerakan dalam permainan. Selain itu, kreativitas anak juga terbentuk dalam setiap teknik permainan yang dilakukannya.

\section{Lirik lagu Cublak-Cublak Suweng: \\ Cublak-cublak suweng, \\ Suwenge teng gelenter, \\ Mambu ketundhung gudel, \\ Pak empo lera-lere \\ Sopo ngguyu ndhelikake, \\ Sir-sir pong dele kopong,}

\section{Cublak-cublak suweng}

Cublak Suweng artinya tempat suweng. Suweng adalah salah satu bentuk perhiasan wanita sejenis anting. Anting ini biasanya dipakai oleh para gadis ataupun wanita yang ada di Jawa. Cublak-Cublak Suweng memiliki arti sebagai ada tempat harta yang berharga, yaitu suweng (suwung, sepi, dan sejati) atau harta sejati.

\section{Suwenge teng gelenter}

Suwenge Teng Gelenter, artinya suweng berserakan. Harta sejati disini dimaknai sebagai suatu kebahagiaan yang sejati dan sudah ditemui di sekitar manusia. 


\section{Mambu ketundhung gudel}

Mambu (baunya) Ketundhung (dituju) Gudel (anak kerbau). Memilik makna, banyak orang yang berusaha mencari harta sejati tersebut. Bahkan orang-orang bodoh (diibaratkan seekor gudel (anak kerbau)) dalam mencari harta itu dengan cara penuh dengan nafsu keegoaan, korupsi, dan keserakahan.

\section{Pak empo lera-lere}

Pak empo (bapak ompong) Lera-lere (menengok kanan-kiri). Orang-orang bodoh itu mirip dengan orang tua ompong (gigi tanggal) yang dilanda kebingungan. Meskipun harta bendanya melimpah, namun ternyata itu hanyalah harta palsu, bukan harta yang sejati atau kebahagiaan yang sejati. Manusia menjadi bingung sendiri karena dikuasai oleh hawa nafsu keserakahannya sendiri.

\section{Sopo ngguyu ndhelikake}

Sopo ngguyu (siapa tertawa) ndhelikake (dia yang menyembunyikan) makna ini mendeskripsikan bahwa barang siapa berlaku bijaksana maka dialah yang akan menemukan tempat yang sebetulnya sebagai harta sejati atau kebahagian sejati. Dia adalah orang yang waspada dan iklas dalam menjalani setiap keadaan hidup, meskipun berada di tengahtengah kehidupan orang-orang yang memiliki sifat serakah.

\section{Sir-sir pong dele kopong}

Sir (hati nurani) pong dele kopong (kedelai kosong tanpa isi). Makna dalam lirik ini adalah menggambarkan hati nurani yang kosong. Manusia dapat menemukan harta sejatinya jika mampu melepaskan harta benda duniawi, mengosongkan diri, tersenyum, ikhlas, rendah hati, tidak merendahkan sesama, serta senantiasa memiliki empati dan membiasakan mengasah tajam hati nuraninya.

Makna dari semua lagu Cublak-Cublak Suweng adalah petuah atau nasehat untuk mencari harta di dunia dengan cara yang baik (halal) dan jujur. Harta yang dicari dengan baik tentunya akan memiliki manfaat di kemudian hari, dibandingkan dengan orang yang mencari harta dengan sifat yang tidak terpuji.

Lagu Cublak-Cublak Suweng biasa dibawakan oleh anak-anak secara beramai-ramai. Pada waktu dahulu biasanya dinyanyikan pada malam hari, karena belum ada televisi sebagai hiburan dan belum ada listrik sebagai penerangan. Dengan bergesernya waktu, lagu dolanan Cublak-Cublak Suwung mulai dinyanyikan siang hari pada saat anak-anak bermain sepulang sekolah. Pada saat ini sudah jarang terdengar anak menyanyikan lagu ini karena sudah tergeser dengan televisi, internet, maupun game. Beberapa waktu yang lalu peneliti masih mendengar lagu ini dinyanyikan oleh beberapa anak-anak taman kanak-kanak pada waktu bermain. Stasiun televisi hampir sering menayangkan lagu anak-anak yang sebetulnya kurang layak untuk dikonsumsi. Mencermati hal tersebut, sebenarnya tidak sesuai dengan perkembangan usia pada anak. Semakin lama keberadaan lagu dolanan anak-anak tradisional semakin tidak dikenal dalam dunia permainan anak-anak.

Lagu Cublak-Cublak Suweng bisa dimanfaatkan sebagai media pendidikan karakter pada anakanak. Karena, terkadung pesan moral kehidupan yang sangat bagus. Anak-anak dapat dikenalkan dengan sifat kejujuran dalam segala aspek kehidupan. Makna nilai jujur di sini adalah jujur dalam bertingkah laku dan jujur dalam pekerjaan.

Lirik Lagu Lir-Ilir:

Lir-ilir, lir-ilir

Tandure wis semilir

Tak ijo royo-royo

Tak sanggo temanten anyar

Cah angon cah angon

Panekno belimbing kuwi

Luyu-luyu yo penekno

Kanggo mbasuh dodotiro

Dodotiro, dodotiro

Kumitir bedhah ing pinggir

Dondomono jlumatono kanggo sebo mengko sore Mumpung padhang rembulane

Mumpung jembar kalangane

yo surako..surak hiyo 
Lir-ilir

Lir-ilir (Bangunlah, bangunlah) dimaknai sebagai suatu gerakan angin sepoi-sepoi sebagai suatu ajakan yang bernada lembut untuk mengingat sang pencipta dengan melakukan zikir. Dengan, berzikir manusia menjadi ing-at pada sang pencipta yang biasa terlena dengan kehidupan duniawi. Manusia kembali berdzikir untuk mengagungkan sang pencipta.

\section{Tandure wis sumilir}

Tandure wis semilir (pohon sudah mulai bersemi) memiliki pohon (diartikan sebagai) kehidupan manusia mulai tertata ibadahnya.

\section{Tak ijo royo-royo}

Tak ijo royo-royo (demikian menghijau) memiliki makna makna manusia sudah mulai mengingat sang penciptanya untuk selalu berdzikir.

\section{Tang sengguh temanten anyar}

Tak sengguh tematen anyar (bagaikan gairah penganten yang baru) memiliki makna ditafsirkan bahwa raja-raja di Jawa pada jaman dahulunya memeluk agama Hindu dan Budha. Raja-raja tersebut ketika agama Islam datang kemudian berpindah ke agama Islam. Perpindahan keyakinan seorang raja diikuti pula oleh para rakyatnya. Semangat untuk belajar Islam sangat tinggi.

\section{Cah angon cah angon}

Cah angon-cah angon (anak pengembala, anak pengembala) ditafsirkan maknanya Sebagai seorang pengembala yang selalu mengarahkan hewan-hewan gembalanya agar tidak tersesat. Pengembala diibaratkan seorang imam. Seorang imam berkewajiban untuk selalu membimbing umatnya di jalan yang benar meskipun banyak rintangannya. Kata "Cah angon" itu dilihat sebagai sebuah seruan lembut kepada para imam, kyai-kyai atau rajaraja, ataupun kaum terpelajar yang merasa mempunyai kewajiban untuk mengarahkan rakyatnya sebagai jamaahnya.

\section{Panekno belimbing kuwi}

Panekno belimbing kuwi (panjatlah pohon belimbing itu) memiliki makna sangat kuat karena buah belimbing adalah buah berwarna hijau dengan lima sisi buah yang bisa di anggap sebagai simbol dari lima rukun Islam. Dalam menjalan syariat rukun Islam maka raja menghimbau kepada masyarakat agar menjalankan syari'at Islam. Jika rukun Islam itu betul-betul dilaksanakan dengan baik maka orang itu dianggap bertakwa. Dari ketakwaannya dapat membersihkan diri dari segala dosa yang pernah diperbuat. Maka dengan menjalankan rukun Islam dengan baik, manusia kembali kefitrahnya menjadi manusia yang bersih.

\section{Lunyu-lunyu yo penekno}

Lunyu-lunyu yo penekno (walau susah tetap panjatlah) memiliki makna bahwa seberat apapun persoalan dalam mengamalkan rukun Islam harus dilalui meskipun jalannya tidak selalu lurus.

\section{Kanggo mbasuh dodotiro}

Kanggo mbasuh dodotiro (berguna untuk pakaianmu). Makna dalam kalimat adalah bahwa pakaian seseorang mencerminkan sebuah kepribadian. Seseorang dihargai orang lain dilihat dari pakaian yang dikenakan. Pakaian di sini diibaratkan sebagai sebuah amal perbuatan seseorang.

\section{Dodotiro, dodotiro}

Dodotiro, dodotiro (pakaian pakaian yang buruk) memiliki makna bahwa pakaian yang sudah usang segera diperbaiki supaya lebih rapi. Bagaimanapun pakaian merupakan suatu cermin diri seseorang. Bukan karena mahalnya tetapi kepantasan pemakainya. Pakaian dibaratkan sebuah amalan perbuatan manusia.

\section{Kumitir bedhah ing pinggir}

Kumitir bedhah ing pinggir (disisihkan dan jahitlah) memiliki makna pakaian-pakaian yang sudah sobek bisa dijahit. Makna ini mengindikasikan bahwa manusia dipenuhi 
dengan perbuatan yang baik dan tidak baik. Sebenarnya makna ini dapat ditafsirkan bahwa orang yang pernah berbuat tidak baik harus segera sadar dan berusaha memperbaikinya.

\section{Dondomono jlumatono kanggo sebo mengko sore}

Dondomono jlumatono kanggo sebo mengko sore (benahilah untuk menghadap nanti sore) memiliki makna untuk merapikan pakaian yang akan dipakai nanti sore. Maksud dari ini sebenarnya manusia harus siap kapan pun menghadapi kematian. Maka untuk itu harus segera memiliki amal perbuatan yang baik. Amal perbuatan yang baik menjadi pintu untuk menghadap Sang Pencipta. Manusia tidak boleh terlena dengan duniawi karena kematian bisa datang kapan saja.

\section{Mumpung padhang rembulane}

Mumpung padhang rembulane (mumpung terang rembulannya) memiliki makna manusia harus menggunakan waktu dengan baik. Karena kematian kapanpun bisa datang. Tidak peduli waktu siang atau malam. Maka di waktu pagi manusia dapat memanfaatkan untuk bekerja mencari nafkah dan malam hari untuk istirahat dan beribadah.

\section{Mumpung jembar kalangane}

Mumpung jembar kalangane (mumpung banyak waktu luang) memiliki makna manusia harus bisa memanfaatkan waktu dengan baik. Waktu tidak boleh disiakan-siakan begitu saja karena tidak akan pernah kembali. Manusia bisa mengisi waktu yang ada untuk hal-hal yang bermanfaat dan beribadah kepada Allah SWT. Seperti yang diajarkan oleh para kyai bahwa para santrinya harus bisa mengisi waktu untuk beribadah kepada-Nya.

\section{Sun Suraka surak hiyo}

Sun Suraka surak hiyo (mari bersorak-sorak hayo) memiliki makna mengajak kepada semua manusia untuk segera melaksanakan syariat agama Islam dengan benar. Dengan menjalankan syariat agama yang benar, maka manusia akan hidup dalam kebenaran dan

\section{ketenteraman.}

Makna dalam lagu ilir-ilir sebenarnya sebagai salah satu pesan moral yang sangat baik untuk dicermati. Walaupun sebenarnya lagu ini termasuk lagu dolanan anak yang dinyanyikan dengan riang. Lagu ini biasanya dibawakan pada malam hari sewaktu terang bulan. Anak-anak biasanya bermain di halaman dengan beberapa orang. Sekarang di perkotaan ataupun di pedesaan sudah jarang dijumpai anak-anak bermain di waktu terang bulan. Yang ada anak sudah mulai dengan kehidupan individual masing-masing. Anak-anak sekarang bermain dengan ditemani $t v$, game, dan gadget. Bahkan dalam satu rumah pun, kakak dan adik sudah bermain sendiri di kamar masingmasing. Sungguh ironis hal ini jika dikaji dari sudut pandang dari ilmu psikologi. Fasilitas kamar yang diberikan kepada anak-anak pun sudah melampaui batas umur yang semestinya. Hal ini menyebabkan anak menjadi pasif dan apatis terhadap sesuatu hal. Yang lebih memprihatinkan anak-anak menjadi kurang empatinya dengan lingkungan sekitar.

Mencermati problem di atas tidak ada salahnya jika sebagai peneliti mulai memperkenalkan kembali lagu-lagu dolanan anak. Lagu dolanan anak sarat dengan muatan agama, pendidikan, moral, kebersamaan, maupun kerjasama. Tembang lir-lir dibuat sebagai cara kepandaian Wali Songo dalam mengajarkan Islam kepada masyarakat Jawa melalui cara yang sangat bijaksana dan santun. Maka kata-kata yang sarat dengan muatan pesan moral ini dirangkai dalam lirik yang indah. Katakata dalam lagu itu seolah kata biasa-biasa saja yang menggambarkan keriangan anak-anak. Jika dipahami dengan sungguh-sungguh akan banyak pesan-pesan agamawi yang terkandung di sana.

\section{Lirik lagu Menthok-menthok:}

Menthok-menthok tak kandhani

Mung solahmu angisin-isini

Bokya aja ndheprok

Ana kandhang wae

Enak-enak ngorok

Ora nyambut gawe

Methok-menthok

Mung lakumu megal-megol gawe guyu 
Menthok-menthok tak kandhani

Menthok-menthok tak kandhani (Menthokmenthok saya nasehati) memiliki makna bahwa sebagai seorang manusia harus mau mendengarkan nasehat dari orang lain. Entah nasehat tersebut berguna untuk dirinya dan membawa kebaikan pada dirinya harus diterima. Manusia secara alamiah dilahirkan ke dunia sebagai makhluk individu dan mahkluk sosial. Secara kodrati manusia akan banyak berinteraksi dengan orang lain.

\section{Mung solahmu angisin-isini}

Mung solahmu angisin-isini (Hanya perilakumu yang memalukan) memiliki makna bahwa manusia dapat membuat perilaku yang memalukan baik dilingkungan keluarga ataupun lingkungan masyarakat. Perilaku ini dapat tercermin ketika membawakan dirinya di lingkungan masyarakat maupun umum. Perilaku yang tidak baik akan membuat malu diri sendiri dan orang lain.

\section{Bokya aja ndheprok}

Bokya aja ndheprok (Jangan hanya diam dan duduk) memiliki makna tentang kemalasan seseorang yang tidak memiliki aktivitas sehingga tidak memiliki manfaat bagi orang lain. Kemalasan akan membawa keburukan bagi dirinya dan keluarganya, bahkan bagi negaranya.

\section{Ana kandhang wae}

Ana kandhang wae (di kandang saja) memiliki makna tentang sindiran kepada manusia yang hanya di rumah tanpa ada aktivitas yang berguna bagi orang lain. Seseorang yang hanya diam di rumah biasanya menjadi kurang pergaulan. Dari kurangnya pergaulan ini mengakibatkan tidak adanya pengalaman sehingga kurang memiliki wawasan yang luas. Biasanya orang yang malas bersilaturahmi ke orang lain biasanya akan jauh dari rejeki.

\section{Enak-enak ngorok}

Enak-enak ngorok (enak-enak mendengkur) memiliki makna tentang seseorang yang memiliki sifat malas bekerja. Biasanya orang seperti biasa memiliki kebiasaan suka tidur tidak tepat pada waktunya. Hampir semua waktunya digunakan untuk tidur. Kebiasaan ini akan berakibat pada kemalasan.

\section{Ora nyambut gawe}

Ora nyambut gawe (tidak bekerja) memiliki makna orang tidak memiliki pekerjaan. Manusia memiliki fitrah sendirinya pada waktu siang hari untuk bekerja sedangkan waktu malam digunakan untuk beribadah dan beristirahat. Seorang laki-laki memiliki kewajiban untuk mencari nafkah dengan bekerja. Bekerja juga merupakan sebuah bentuk ibadah.

\section{Menthok-menthok}

Menthok-menthok (menthok-menthok) memiliki makna untuk menyebut salah satu nama hewan. Hewan ini terkenal dengan sifat pemalasnya. Jadi jika manusia memiliki sifat pemalas maka dapat disamakan hewan menthok-menthok (sejenis unggas).

\section{Mung lakumu megal megow gawe guyu}

Mung lakumu megal-megol gawe guyu (hanya jalanmu meggoyangkan pantat membuat orang tertawa) memiliki makna bahwa orang pemalas biasanya hanya memiliki satu pekerjaan yaitu tidur. Biasanya orang seperti ini memiliki badan yang gemuk (tidak ideal) sehingga cara jalannya pun seperti menthok (hewan sejenis unggas).

Makna keseluruhan dalam lirik lagu dolanan 'Menthok-menthok' mengandung pesan moral yang sangat baik untuk zaman sekarang ini. Perilaku manusia yang malas-malasan ternyata berdampak buruk terhadap keluarga dan lingkungan. Perilaku dengan cara menutup diri dari orang lain tidak akan membawa perubahan yang baik pada dirinya. Dengan membuka diri maka pengetahuan dan pengalaman akan membawa manfaat yang luar biasa. Orang yang mau belajar dari orang lain biasanya membawa kesuksesan di masa mendatang. Sifat sombong yang tidak mau mendengarkan 
orang lain biasanya membawa malapetaka bagi dirinya sendiri.

Anak-anak dapat diajarkan tentang pendidikan karakter pada lagu ini. Media musik dapat digunakan sebagai penanaman karakter yang kuat pada anak. Karena, musik memang merupakan hal yang sangat menarik dan menyenangkan bagi anak-anak. Tanpa sadar mereka sudah bisa diperkenalkan pendidikan karakter. Maka teknik stimulasi musik pada anak-anak melalui pemaknaan lagu dolanan anak-anak memang sudah sangat tepat untuk diterapkan.

\section{Lirik lagu Padhang Bulan:}

Yo prakanca dolanan ing njaba

Padhang mbulan padhangé kaya rina

Rembulané kang ngawé-awé

Ngélikaké aja turu soré-soré

\section{Yo prakanca dolanan ing njaba}

Yo prakanca dolanan ing njaba (Ayo temanteman bermain diluar) lirik ini memiliki makna bahwa manusia memperoleh semua fasilitas di muka bumi dengan kemegahan jagad alam raya ini adalah karunia Allah SWT. Maka sudah sepantasnya harus dapat mensyukuri semua nikmat yang diberikan.

\section{Padhang mbulan padhangé kaya rina}

Padhang mbulan padhangé kaya rina (cahaya bulan yang terang benderang) lirik ini memiliki makna bahwa Allah menciptakan semua lengkap sistem tata surya di dunia ini dengan sangat sempurna. Ada bulan, matahari, planet, bumi, dan sebagainya yang berfungsi untuk menopang kehidupan manusia. Sejak kita masih kanak-kanak sering orangtua menyanyikan lagu padhang bulan. Dengan harapan, kecantikan anaknya menyerupai bulan. Begitu, kita beranjak remaja baru sadar bahwa bulan memiliki daya tarik yang begitu indah. Cahayanya yang menerangi dunia ketika malam tiba. Sementara, satu malam tanpa kehadiran cahaya bulan dan bintang maka langit terasa gelap dan keindahan seakan pudar begitu saja.

\section{Rembulané kang ngawé-awé}

Rembulané kang ngawé-awé (rembulan yang seakan-akan melambaikan tangan) lirik ini memiliki makna manusia dilahirkan ke dunia ini melalui proses yang panjang. Semuanya sudah diatur oleh Allah SWT. Mulai kapan seorang ibu mengandung sampai kapan dia lahir, dan sebagainya. Maka sebagai wujud syukur atas semua karunianya sudah kewajiban manusia bersyukur kepada-Nya. Syukur itu diwujudkan dalam bentuk beribadah dengan jalan bertakwa kepada-Nya. Hasil dari ketakwaannya akan diperoleh kehidupan yang serasi dan seimbang antara dunia dan akherat kelak.

\section{Ngélikaké aja turu soré-soré}

Ngélikaké aja turu soré-soré (mengingatkan kepada kita untuk tidak tidur sore-sore) lirik ini memiliki makna Tuhan menciptakan manusia sebagai makhluk yang memiliki budi pekerti yang tinggi. Maka sudah sepantasnya, manusia sebagai makhluk yang memiliki harkat dan martabat yang luhur selalu mengingat karunia sang pencipta dengan beribadah. Tuhan menciptakan waktu siang dan malam. Manusia menggunakan waktu siang untuk bekerja sedangkan waktu malam untuk beristirahat dan beribadah.

Secara keseluruhan makna dalam lagu yang berjudul Padhang Bulan ini adalah mengajarkan manusia untuk bersyukur atas karunia Tuhan dengan jalan menjalankan ibadah dengan baik. Karunia Tuhan yang begitu besar dan sangat bermanfaat bagi sumber kehidupan manusia mestinya menjadi bahan perenungan manusia untuk selalu ingat kepada-Nya.

Lagu Padhang Bulan biasanya dinyanyikan anak-anak pada zaman dulu waktu malam hari bersama-sama di halaman sambil bermainmain. Lagu ini bernada riang dan liriknya cukup sederhana untuk dihafalkan anak-anak. Lirik yang disusun dengan lirik yang sangat bagus ternyata masih populer sekarang ini. Walaupun, saat ini lirik sudah dinyanyikan dengan musik yang 
kontemporer (versi yang berbeda) tetapi masih memiliki ciri khas yang menandakan lagu dolanan anak-anak Padhang Bulan. Lagu ini memiliki jenis nada riang sehingga dibawakan anak-anak dengan gerakan dinamis. Dari pendidikan karakter pun bisa dipetik nilainya ketika mendengarkan lantunan ritme musik dinamis yang memberikan efek positif kepada anak untuk bisa mengendalikan emosi. Rata-rata anak-anak masih memiliki tingkat emosi yang masih labil. Salah satunya bisa menggunakan terapi musik untuk dapat menjaga kestabilan emosi. Emosi merupakan hal yang sangat vital menjaga kesehatan tubuh manusia. Berbagai penelitian menyimpulkan bahwa penyakit sebenarnya berasal dari dalam diri manusia sendiri. Salah satu penyebabnya adalah tidak bisa mengolah emosi dengan baik dalam dirinya.

\section{Lirik lagu Sluku-Sluku Bathok:}

Sluku-sluku bathok, bathoke ela-elo

Si Rama menyang Sala, oleh-olehe payung motha Mak jenthit lolo lobah, wong mati ora obah

Nek obah medeni bocah, nek urip goleka dhuwit

\section{Sluku-sluku bathok, bathoke ela-elo}

Sluku-sluku bathok, bathoke ela-elo (ayunayun kepala, kepalanya geleng geleng) memiliki makna bahwa manusia harus selalu ingat kepada Sang penciptanya dengan cara berdzikir untuk menganggungkan asma-Nya.

\section{Si Rama menyang Sala, oleh-olehe payung motha} Si Rama menyang Sala, oleh-olehe payung motha (si bapak pergi ke Sala, oleh-olehnya payung mutha) memiliki makna bahwa manusia secara fitrahnya memikul tanggung jawab untuk mencari nafkah di dunia. Mencari nafkah merupakan salah satu bentuk ibadah. Manusia dapat menggunakan harta bendanya untuk beribadah di jalan Allah.

\section{Mak jenthit lolo lobah, wong mati ora obah} Mak jenthit lolo lobah, wong mati ora obah (secara tiba-tiba begerak, orang mati tidak bergerak) memiliki makna bahwa orang yang mati sudah terputus hubungannya dengan urusan duniawi. Harta yang diperoleh semasa hidupnya kelak akan dimintai pertanggung jawaban di alam akherat.

Nek obah medeni bocah, nek urip goleka dhuwit Nek obah medeni bocah, nek urip goleka dhuwit (kalau bergerak menakuti orang, kalau hidup carilah uang) memiliki makna bahwa ketika manusia mati hanya membawa amalannya ketika di dunia, keluarga maupun harta benda tidak akan menemaninya, hanya amalanamalan baiknya saja yang akan menemani.

Lagu dolanan anak-anak"Sluku-Sluku Bathok" memiliki makna secara keseluruhan bahwa manusia secara fitrah dilahirkan ke dunia untuk bersyukur dan menginggat kepada Tuhan-Nya. Bentuk ungkapan syukur diwujudkan dengan beribadah dan bertakwa kepada-Nya. Selain itu, secara kodrati manusia berkewajiban untuk mencari nafkah untuk keluarga dan jalan beribadah.

Lagu dolanan anak-anak"Sluku-Sluku Bathok" biasa dimainkan anak-anak pada waktu malam. Lagu ini memiliki ritme yang selaras. Nada yang selaras ini mempengaruhi jiwa perkembangan emosi maupun karakter anak. Pembentukan Karakter lebih optimal diberikan anak-anak sejak kecil. Hasilnya akan lebih baik dibandingkan pembentukan karakternya masa remaja.

\section{Penutup}

Pembentukan karakter pada anak-anak harus dimulai ketika pada masa kanak-kanak. Pembentukan karakter pada anak dapat dilakukan dengan teknik stimulasi melalui musik. Musik dapat digunakan sebagai media untuk membantu mengatur tingkat emosional. Pada masa anak-anak tingkat emosinalnya masih labil.

Lagu dolanan anak-anak dalam upaya pembentukan karakter anak dapat dikelompokkan sebagai berikut: (1) Lagu-lagu dolanan anak tradisional yang liriknya berisi tentang pengetahuan; (2) Lagu dolanan anak tradisional yang liriknya mengandung nilai-nilai pendidikan; dan (3) Lagu dolanan anak tradisional yang berisi permainan 
atau dolanan. Lagu dolanan anak ini sudah mulai bergeser seiring dengan perkembangan zaman. Lagu dolanan anak sudah mulai tergantikan dengan permainan game, gadged, internet dan sebagainya.

\section{Kepustakaan}

Bearl, Nancy; Miller, Gloria Bley. 2003. Rahasia Mengajarkan Seni Pada Anak. Yogyakarta: Pripoenbooks. Tim. 2010.

Buku Pedoman Kelompok Bermain dan TKIT Mutiara Insan Utama.

Bogdan, Robert C. \&Biklen, Sari Knopp.1982. Qualitative research for education: An introduction to theory and methods. USA: Allyn and Bacon.

Eti, Nurhayati. 2011. Psikologi Pendidikan Inovatif. Yogyakarta: Pustaka Pelajar

Hastanto, Sri. 2011. Kajian Musik Nusantara-1 Surakarta: ISI Press.

Kartini, Yuyun. 2014. Tembang Dolanan AnakAnak Berbahasa Jawa Sumber Pembentukan Watak dan Budi Pekerti. Surabaya: Balai Bahasa.

Marvin W. Berkowitz. 2002. "The Science of Character Education" dalam William Damon (ed). Bringing in a New Era in Character Education. California: Hoover Institution Press.
Miles, M.B. dan Huberman A.M. 1984. Qualitative data analysis: A sourcebook of a new methods. Berverly Hills: Sage Publication.

Ning, Endah Khoiriyah. 2006. "Variasi Seni Rupa dalam Pembelajaran Anak Usia Dini”. [Skripsi]. Universitas Negeri Semarang.

Prasetya, Agus. 2008. “Tokoh Bambang Ekalaya dan Moralitas Pendidikan" dalam Jurnal Resital Vol. 9 No.1.Juni.

Syuhendri. 2008. "Tradisi sebagai Wadah Ketahanan Budaya: Sebuah Kritik Terhadap Kapitalisme Dan Budaya Pasar" dalam Jurnal Resital. Vol.9 No.1. Juni.

Soemaryatmi. 2010. "Pendidikan Karakter" Melalui Model Pembelajaran Interaktif Mata Kuliah Koreografi. Surakarta: P3AI ISI Surakarta.

Sholehudin, M. 2000. Konsep Dasar Pendidikan Prasekolah. Bandung: Fakultas Ilmu Pendidikan Indonesia.

Suharko, Kasaran. (Ketua Komisi Nasional Budi Pekerti). (wawancara Buletin Siang RCTI, 11 Mei 1999).

Spradley, James. P. 2007. The Etnographic Interview. Yogyakarta: PT Tiara Wacana.

\section{Narasumber}

Suharji. 53 tahun. Staf pengajar Institut Seni Indonesia Surakarta. 